\title{
Symptomatology of children in contact with sea water contaminated with sewage
}

\author{
L M Alexander, A Heaven, A Tennant, R Morris
}

\begin{abstract}
Study objective-The aim was to determine whether or not there was a measurable risk of ill health associated with contact with sea water for children between the ages of 6 and 11 years old.

Design and Setting-This was a prospective survey carried out on Blackpool beach. Parents of children between the ages of 6 and 11 years were interviewed over a seven week period during July, August, and September, 1990. Respondents were followed up 10-14 d after the original interview by either telephone or post. Water samples were collected on each day of the survey.
\end{abstract}

Participants-939 interviews with parents or guardians were completed on the beach; $857(91.9 \%)$ of these persons agreed to a follow up interview. The results of this study are based on 703 cases of matched data, of good quality, collected for each child on the beach and during a follow up interview.

Main results-Non-compliance with the European Community microbiological imperative standards for recreational waters at Blackpool Tower and South Pier sampling sites, respectively, ranged between: $6 \%$ and $7 \%$ for total coliforms; $13 \%$ and $25 \%$ for faecal coliforms; $69 \%$ and $80 \%$ for faecal streptococci (Guide standard); $50 \%$ and $67 \%$ for salmonellae and $73 \%$ and $88 \%$ for enteroviruses. There was a significant overall increase in the mean number of symptoms reported for each child $(p<0.001)$. However, the prevalence of certain symptoms increased significantly only in those children who had been in contact with the water on the day of the beach interview. These symptoms included vomiting $(p<0.0009)$, diarrhoea $(p<0.0001)$, itchy skin $(p<0.0009)$, fever $(p<0.0013)$, lack of energy $(p<0.0007)$, and loss of appetite $(p<0.0227)$. None of the other variables investigated could account for the significant increase in the reported symptom experience of those children in contact with sea water contaminated with sewage.

Conclusions-Children who come into contact with contaminated sea water are likely to develop symptoms as a result.

f Epidemiol Community Health 1992; 46: 340-343

More than 15 years have passed since the Council of the European Communities instituted a directive concerning the quality of bathing waters. ${ }^{1}$ By setting water quality standards, the directive aimed to reduce pollution in bathing waters and to protect the public's health. It called for the identification of those bathing waters where bathing is "traditionally practised" or "explicitly authorised".

The directive stipulates that for total and faecal coliform bacteria, water samples should be collected at fortnightly intervals. The determination of faecal streptococci, salmonellae, and enteroviruses need only be carried out when "an inspection of the bathing area shows that the substance (sewage) may be present or that the quality of the water has deteriorated".

Since 1959, when it was concluded that “. . . bathing in sewage-polluted sea water carries only a negligible risk to health, even on beaches that are aesthetically very unsatisfactory", 2 there have been a number of studies that have contradicted this assertion. ${ }^{34}$ The symptoms which have been found to be associated with exposure to recreational waters contaminated with sewage include: gastrointestinal symptoms, ${ }^{5-12}$ ear and eye symptoms, ${ }^{812-15}$ skin irritation, 813 and respiratory ailments. ${ }^{13}$ Based upon data gathered using prospective designs, the United States Environmental Protection Agency concluded that "... the studies have unequivocally established that there is a risk of gastrointestinal illness associated with swimming in polluted waters and that the risk increases as the water quality decreases". 11

There are other factors known to augment this risk, including age and visitor's status. With respect to the latter, residents exposed to pathogens found in local sewage have been shown to develop fewer symptoms than non-residents or visitors. ${ }^{9}$ With the exception of the elderly and the chronically ill, children are more vulnerable to infection than adults, ${ }^{10}$ and with respect to recreational bathing, children are more likely to swim, paddle, or play by the water than either the elderly or the chronically ill.

In Britain, two research groups have included children in investigations of the health effects of bathing. In a cross sectional study, ${ }^{5}$ one child under 15 years old was included in a survey at two unnamed resorts. In a second prospective investigation at Langland Bay, approximately $23 \%$ $(n=178)$ of the total follow up sample were children 5-14 years old. ${ }^{4}$ As evidence from outside the United Kingdom suggests that children are more susceptible than adults, ${ }^{10}$ it is important to examine health consequences of bathing for children in Britain, where climate, bathing season, and bathing patterns are markedly different. Furthermore, there has been no work in 
Britain which has assessed the health effects of bathing in waters which have continually failed to meet the European directive imperative standards for recreational waters. In Lancashire, in the north west of England, all of the 11 designated bathing waters, including Blackpool, failed to meet the imperative standard during the 1990 bathing season.

The aim of this study was to investigate the health risks associated with exposure to sea water, using a sample composed exclusively of children, on a British beach which has consistently failed to meet the imperative standards for designated bathing waters.

\section{Methods}

GENERAL

Water samples and survey data, the latter based on interviews with parents or guardians, were collected on seven weekends during July, August, and September, 1990. The study area was defined as that stretch of beach, approximately $2 \mathrm{~km}$ long, extending from Blackpool Tower to South Pier, and is hereafter referred to as Blackpool beach.

\section{MICROBIOLOGICAL}

In the light of previous data on water quality at Blackpool, sewage contamination was suspected and water quality tests were undertaken for each of the five microorganisms detailed in the EC directive.

On each day that interviewing was carried out, two 11 litre water samples were collected at waist depth on an incoming or high tide, one from each of two sampling points. These were located at the northernmost boundary of the study area (opposite Blackpool Tower) and at the southernmost boundary of the study area (the northern side of South Pier).

All samples were transported by courier to a laboratory for microbiological analyses and assayed for total coliforms, faecal coliforms, faecal streptococci, salmonellae, and enteroviruses. Standard methods for the detection and/or enumeration of pathogens were used in all cases. ${ }^{16-18}$

Water sampling at Blackpool beach was undertaken concurrently with additional sampling at other sites. To ensure that knowledge of the location of a water sample did not influence the microbiological analyses, all locations from all sites were haphazardly coded and the code was not broken until after all of the analyses had been completed.

STUDY DESIGN

A prospective design, similar to that adopted by WHO, ${ }^{3}$ Cabelli, ${ }^{9}$ and Dufour, ${ }^{11}$ was used in this study which focused exclusively on children between the ages of 6 and 11 years.

The study began on the first weekend of primary school summer holidays and employed female interviewers who had undergone a minimum of four days in-house training. As far as possible, all adults on the Blackpool beach, with children who appeared to be of the requisite age, were approached by the interviewers and asked if they would participate in a survey on the leisure activities and general health of children. Once agreement for an interview was obtained and the child's age was determined to be between 6 and 11 years, the interview continued. If more than one child was present, the parent or guardian was asked to give the first name of one child only. Wherever possible, information from mothers or female guardians was sought.

Each beach interview lasted for approximately 15 minutes. Information was obtained about the child in question, with particular reference to: sex, age, visits to other beaches, number of siblings under 5 years of age, general pattern of leisure activity during the summer, general health, and chronic or recurring illness. In addition, information on water exposure (frequency, duration, and type of contact), foods consumed and symptoms, as well as indicators of severity, was collected for the day of the interview and for the two days before. Symptom experiences for all family members, for the day of the interview and the prior two days, were also recorded, as was the sex of the interviewee and his or her name. Finally, the respondents were requested to participate in a second interview in 10 to 14 days time. Telephone follow ups were arranged whenever possible. Postal follow ups were used only when a respondent could not, or would not, be contacted by telephone.

Follow up interviews collected information pertaining to the intervening period on the same variables as those initially investigated with the addition of household income.

Postal questionnaires, addressed to the respondents, were posted $9 \mathrm{~d}$ after the beach interview, anticipating arrival on day 10. Telephone follow up interviews began on day 10 . If after $14 \mathrm{~d}$ no contact was made with the respondent, or if a postal questionnaire had been completed after the 14 days had elapsed, no further contact was attempted, or the postal reply was discarded.

\section{STATISTICAL ANALYSES}

The McNemar test, ${ }^{19}$ for matched pairs, was used to test for differential symptom effects in those children who were in contact with the water and those who were not in contact with the water.

The McNemar test, Pearson's correlation, $t$ test, and the $\chi^{2}$ statistic were used to assess the association $(p<0.05)$ between water contact and other variables which might have influenced symptom experiences in the two groups.

\section{Results}

MICROBIOLOGICAL

Dangerous sea conditions prohibited the collection of water samples from the Blackpool Tower site on one day during the survey. Fifteen samples were assayed from this site as compared with 16 from the South Pier site. Overall, $80 \%$ of the samples at the Blackpool Tower site and $93 \%$ of the samples at the South Pier site failed overall to meet the European Community Standards set down for recreational waters. Percentage failure for each of the five requisite measures, for the Blackpool Tower site and the South Pier site respectively, was: $6.7 \%$ and $6.3 \%$ for total coliforms; $13.3 \%$ and $25.0 \%$ for faecal coliforms; $80.0 \%$ and $68.8 \%$ for faecal streptococci; $66.7 \%$ and $50.0 \%$ for salmonellae; and $73.3 \%$ and $87.5 \%$ 
for enteroviruses. Table I tabulates the geometric mean concentrations of the five pathogens investigated.

HEALTH SURVEY

Although the air temperature remained relatively constant on those days that beach interviews were carried out $\left(18-24^{\circ} \mathrm{C}\right)$, weather conditions were highly variable and cloud, rain/drizzle, and sunshine were recorded at Blackpool airport for eight, five, and three days, respectively. This resulted in varying numbers of people on the beach during the survey. The number of interviews completed on any given day ranged from 13 to 119 and on three days no interviews were completed.

We successfully completed 939 interviews. The characteristics of the beach sample are detailed in table II. Of the respondents, $857(91.9 \%)$ agreed to take part in the follow up survey. Of these 857, $719(83.9 \%)$ were contacted successfully, 598 by telephone $(83.2 \%)$ and 121 by post $(16.8 \%)$. In addition to those people who were unobtainable within the 10 to $14 \mathrm{~d}$ window, contact could not be made with 16 people $(1.7 \%)$ because an incorrect address or telephone number was given to, or recorded by, the interviewer.

No significant differences were found between either: (1) the respondents to the beach interview who agreed to participate in the follow up study and those who did not; or (2) any of the water exposure variables and agreement to participate in a follow up interview. Nor were there any signifi-

Table I Summary of the microbiological water quality at the study area. Values are geometric means.

\begin{tabular}{lcc}
\hline Organism & $\begin{array}{l}\text { Blackpool Tower } \\
(n=15)\end{array}$ & $\begin{array}{l}\text { South Pier } \\
(n=16)\end{array}$ \\
\hline Total coliforms & 1896 & 2141 \\
Faecal coliforms & 895 & 826 \\
Faecal streptococci & 290 & 139 \\
Salmonella & $\dagger$ & $\dagger$ \\
Enteroviruses & 4 & 2
\end{tabular}

t Salmonella were present in $67 \%$ and $50 \%$ of the Blackpool Tower and the South Pier samples, respectively. Their absolute numbers were not determined.

Table II Characteristics of the beach sample $(n=939)$.

\begin{tabular}{|c|c|}
\hline Variable & Percent \\
\hline $\begin{array}{l}\text { Child's sex } \\
\text { male } \\
\text { female }\end{array}$ & $\begin{array}{l}47 \cdot 2 \\
52 \cdot 8\end{array}$ \\
\hline $\begin{array}{l}\text { Child's age (years) } \\
6 \\
7 \\
8 \\
9 \\
10 \\
11\end{array}$ & $\begin{array}{l}18 \cdot 8 \\
19 \cdot 7 \\
18 \cdot 0 \\
15 \cdot 7 \\
15 \cdot 0 \\
12 \cdot 8\end{array}$ \\
\hline $\begin{array}{l}\text { Child's general health } \\
\text { very good } \\
\text { good } \\
\text { fair } \\
\text { poor } \\
\text { very poor } \\
\text { not recorded }\end{array}$ & $\begin{array}{r}74 \cdot 6 \\
20 \cdot 9 \\
3 \cdot 4 \\
0 \cdot 1 \\
0 \cdot 1 \\
1 \cdot 1\end{array}$ \\
\hline $\begin{array}{l}\text { Siblings under } 5 \text { years old } \\
\text { yes } \\
\text { no }\end{array}$ & $\begin{array}{l}47 \cdot 6 \\
52 \cdot 4\end{array}$ \\
\hline $\begin{array}{l}\text { Child's status } \\
\text { day tripper } \\
\text { holidaymaker } \\
\text { resident of Blackpool }\end{array}$ & $\begin{array}{r}41 \cdot 1 \\
56 \cdot 9 \\
1 \cdot 6\end{array}$ \\
\hline $\begin{array}{l}\text { Respondent's sex } \\
\text { male } \\
\text { female } \\
\text { male and female } \\
\text { not recorded }\end{array}$ & $\begin{array}{r}8 \cdot 1 \\
77 \cdot 8 \\
7 \cdot 3 \\
6 \cdot 8\end{array}$ \\
\hline $\begin{array}{l}\text { Participation in follow up } \\
\text { yes } \\
\text { no }\end{array}$ & $\begin{array}{r}91.9 \\
8.1\end{array}$ \\
\hline
\end{tabular}

cant effects which could be attributed to interviewer bias, which was assessed by analysis of variance on randomly chosen variables.

THE MATCHED SAMPLE

Data analyses were carried out on 703 of the 719 matched data sets after discarding 16 follow up cases due to poor data quality.

The 703 cases were allocated into two groups, namely those children who had been in contact with the water and those who had not been in contact with the water at Blackpool beach, at the time of the beach interview. "Contact" was defined as swimming, paddling, or playing by the water.

Comparison of the characteristics of the contact and no contact groups revealed that they did not differ significantly by sex of the respondents, household income, sex of the children, age of the children, the children's general health, number of siblings under 5 years old, visitor's status, or type of follow up interview.

The prevalence of individual symptoms was recorded for each child both on the beach (time 1) and during the follow up interview (time 2). Table III compares the prevalence of symptoms at time 1 and time 2 for all cases, and for contact and no contact groups. There was a strong trend towards an increased reporting of symptoms at time 2 . For all cases, 22 of the 29 symptoms were reported more frequently at time 2 and there was an $11.7 \%$ decrease in children with no symptoms. The mean number of symptoms, per child, at time 1 was 0.7738 as compared with 1.2560 at time 2 $(\mathrm{t}=7.08, \mathrm{p}<0.001)$.

Statistically significant increases were found for 12 of the matched symptom experiences in the contact and the no contact groups (table IV). Four of these changes were significant in both groups. Of the remaining eight changes, seven occurred only in the contact group $\left(\chi^{2}=4.5, p<0.0250\right)$.

The four symptoms which showed significant increases in both groups were sore throat, nausea/ feeling sick, stomach pains/cramps, and headache. Blocked nose was significant in the no contact group, and the seven symptoms which showed significant changes in the contact group were vomiting, diarrhoea, fever, lack of energy, loss of appetite, itchy skin, and sunburn. Further analyses showed no correlation between itchy skin and sunburn, indicating that the former was not a consequence of the latter.

Four indicators were used as surrogate measures of the severity of the symptoms, namely remaining indoors, remaining in bed, consulting a general practitioner, and/or receiving medication. Of those children in the no contact group, $1.6 \%$ stayed indoors, $1.6 \%$ remained in bed, and $6.9 \%$ consulted a general practitioner, as compared with $3.5 \%, 2.6 \%$, and $4.4 \%$ respectively in the contact group. There was, however, a significant increase in the number of children who received medication following their visits to Blackpool beach in both the no contact group $(n=230$, $\mathrm{p}<0.0051)$ and the contact group $(n=423$, $\mathrm{p}<0.0002$ ).

Increases in the reporting of symptoms in the contact group were not found to be associated with any of the following variables: household income; sex of the respondent; sex of the child; 
general health; chronic or recurring illness in the child; age of the child; foods eaten (ice cream, dairy products, chicken, hamburgers, shellfish and ice cubes); acute symptoms in other household members; the presence of children 5 years old or younger in the household; whether or not the follow up interview was carried out by telephone or post, and water related activity between the two interviews. The consumption of hot dogs was associated with both sunburn $(p<0.0226)$ and headache $(p<0.0496)$.

\section{Discussion}

The increase in the reporting of children's symptoms may have been due to sensitisation as a result of the first interview. However, the reporting of some symptoms did decrease and therefore sensitisation would not reasonably explain the patterns of change in symptoms overall or between the contact and no contact groups.

The key symptoms in this study were vomiting, diarrhoea, fever, itchy skin, lack of energy, and loss of appetite. All of these symptoms were significant in the contact group only and can result from microbiological pathogens, such as

Table III The prevalence of symptoms at time 1 and time 2 , all cases, contact and no contact groups.

Table IV Symptoms which showed significant increases in the no contact and contact groups.

\begin{tabular}{|c|c|c|c|c|c|c|}
\hline \multirow[b]{3}{*}{ Symptom } & \multicolumn{6}{|c|}{ Prevalence $(\%)$} \\
\hline & \multicolumn{2}{|c|}{$\begin{array}{l}\text { All cases } \\
(n=703)^{\star}\end{array}$} & \multicolumn{2}{|c|}{$\begin{array}{l}\text { Contact } \\
(n=455)\end{array}$} & \multicolumn{2}{|c|}{$\begin{array}{l}\text { No contact } \\
(n=248)^{\star}\end{array}$} \\
\hline & $t_{1}$ & $t_{2}$ & $t_{1}$ & $t_{2}$ & $t_{1}$ & $t_{2}$ \\
\hline $\begin{array}{l}\text { Runny nose } \\
\text { Blocked nose } \\
\text { Red eyes } \\
\text { Sore or itchy eyes } \\
\text { Sore throat } \\
\text { Dry cough } \\
\text { Cough with phlegm } \\
\text { Ear infection } \\
\text { Itchy ears } \\
\text { Runny ears } \\
\text { Nausea/feeling sick } \\
\text { Indigestion } \\
\text { Stomach pains/cramps } \\
\text { Vomiting } \\
\text { Diarrhoea } \\
\text { Breathing difficulties } \\
\text { Wheezing } \\
\text { Chest pains } \\
\text { Skin rash } \\
\text { Itchy skin } \\
\text { Sunburn } \\
\text { Cuts/bruises } \\
\text { Stings/bites } \\
\text { Headache } \\
\text { Backache } \\
\text { Aching joints } \\
\text { Fever } \\
\text { Lack of energy } \\
\text { Loss of appetite } \\
\text { No symptoms }\end{array}$ & $\begin{aligned} 9 \cdot 5 \\
5 \cdot 1 \\
3 \cdot 3 \\
3 \cdot 0 \\
3 \cdot 1 \\
4 \cdot 8 \\
2 \cdot 4 \\
1 \cdot 1 \\
0 \cdot 0 \\
0 \cdot 6 \\
2 \cdot 6 \\
0 \cdot 3 \\
4 \cdot 1 \\
0 \cdot 9 \\
1 \cdot 6 \\
0 \cdot 9 \\
1 \cdot 6 \\
0 \cdot 3 \\
1 \cdot 6 \\
1 \cdot 3 \\
3 \cdot 4 \\
15 \cdot 8 \\
2 \cdot 7 \\
4 \cdot 7 \\
0.4 \\
1 \cdot 0 \\
0.7 \\
0.7 \\
1.7 \\
57 \cdot 5\end{aligned}$ & 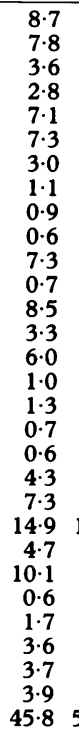 & 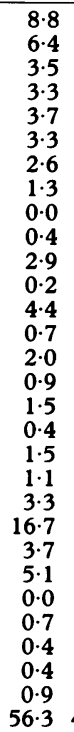 & $\begin{aligned} & 7 \cdot 3 \\
& 3 \cdot 1 \\
& 3 \cdot 1 \\
& 7.5 \\
& 5 \cdot 5 \\
& 2 \cdot 6 \\
& 0 \cdot 9 \\
& 0 \cdot 9 \\
& 0 \cdot 4 \\
& 7 \cdot 9 \\
& 0.9 \\
& 8 \cdot 8 \\
& 4 \cdot 2 \\
& 7.9 \\
& 0.9 \\
& 1 \cdot 1 \\
& 0.7 \\
& 0.4 \\
& 5.1 \\
& 8.4 \\
& 14 \cdot 3 \\
& 5.9 \\
& 9.7 \\
& 0.2 \\
& 1.8 \\
& 3.5 \\
& 3.7 \\
& 4 \cdot 0 \\
& 45 \cdot 5\end{aligned}$ & $\begin{array}{r}10.9 \\
2.8 \\
2.8 \\
2.4 \\
2.0 \\
7.7 \\
2.0 \\
0.8 \\
0.0 \\
0.8 \\
2.0 \\
0.4 \\
3.6 \\
1.2 \\
0.8 \\
0.8 \\
1.6 \\
0.0 \\
1.6 \\
1.6 \\
3.6 \\
14.1 \\
0.8 \\
4.0 \\
1.2 \\
1.6 \\
1.2 \\
1.2 \\
2.4 \\
59.7\end{array}$ & $\begin{array}{r}7.3 \\
8.9 \\
4.4 \\
2.4 \\
6.5 \\
10.5 \\
3.6 \\
1.6 \\
0.8 \\
0.8 \\
6.0 \\
0.4 \\
8.1 \\
1.6 \\
2.4 \\
1.2 \\
1.6 \\
0.8 \\
0.8 \\
2.8 \\
5.2 \\
16.1 \\
2.4 \\
10.9 \\
1.2 \\
1.6 \\
3.6 \\
3.6 \\
1.2 \\
46.4\end{array}$ \\
\hline
\end{tabular}

^ Base numbers may vary slightly due to missing values.

\begin{tabular}{|c|c|c|}
\hline \multirow[b]{2}{*}{ Symptom } & \multicolumn{2}{|c|}{ Significance ( $p)$} \\
\hline & $\begin{array}{l}\text { No contact } \\
(n=248)\end{array}$ & $\begin{array}{l}\text { Contact } \\
(n=455)\end{array}$ \\
\hline $\begin{array}{l}\text { Blocked nose } \\
\text { Sore throat } \\
\text { Nausea/feeling sick } \\
\text { Stomach pains/cramps } \\
\text { Vomiting } \\
\text { Diarrhoea } \\
\text { Itchy skin } \\
\text { Sunburn } \\
\text { Headache } \\
\text { Fever } \\
\text { Lack of energy } \\
\text { Loss of appetite } \\
\text { Gastrointestinal } \\
\text { Skin }\end{array}$ & $\begin{array}{l}0.0026 \\
0.0309 \\
0.0414 \\
0.0347 \\
\text { N.S. } \\
\text { N.S. } \\
\text { N.S. } \\
\text { N.S. } \\
\text { 0.0071 } \\
\text { N.S. } \\
\text { N.S. } \\
\text { N.S. } \\
\text { N.S. } \\
\text { N.S. }\end{array}$ & $\begin{array}{l}\text { N.S. } \\
0.0104 \\
0.0010 \\
0.0061 \\
0.0009 \\
0.0001 \\
0.0009 \\
0.0006 \\
0.0081 \\
0.0013 \\
0.0007 \\
0.0227 \\
0.0001 \\
0.0425\end{array}$ \\
\hline
\end{tabular}

2 Defined as: vomiting + diarrhoea.
2 Defined as: skin rash + itchy skin those detected in the water on each day of this study. These results indicate a strong association between symptom experience and contact with sea water contaminated with sewage.

Nonetheless, it is important to consider other factors which may explain the results of this study. Respondent bias is one potential factor although the pattern of symptom reporting would not support this contention. Respondents would have needed to realise the focus of the study and that the child would subsequently be assigned to a contact or no contact group. In addition, they would have needed to be familiar with the symptoms expected to arise as a result of contact with sea water contaminated with sewage.

Another possible explanation for the findings is the spread of infection between children. This phenomenon is unlikely to account for the results of this study as the spread of infection is less likely in an open air environment, and secondly, the study took place on weekends only. Many of the children were not on the beach, or in Blackpool, at the same time as others.

An alternative explanation is that the contact group was different from the no contact group in a way which would explain the differential increase in symptom experiences. However, there were no significant differences between sociodemographic variables, foods eaten, or information on any of the other variables collected. In addition, there was no significant difference in the attitudes of the respondents in the contact and no contact groups towards their children swimming, paddling, or playing in the sea along the Lancashire coast. It does remain possible that the association between symptom experience and another unknown variable would account for the results. However, in view of the fact that the sea water at Blackpool is contaminated with sewage, contact with contaminated water is the most likely explanation.

Financial constraints made it impossible to obtain more water samples and for this reason no attempt has been made to correlate symptom experience with individual pathogens found in the water. Due to daily variations in the numbers of beach goers and completed beach interviews, closer scrutiny of the data by date of exposure did not prove meaningful, even though water samples met the imperative standards for three days at the Blackpool Tower site and for one day at the South Pier site. However, it is important to note that these standards are not based on health related data, that the water at Blackpool beach is contaminated with raw sewage on a daily basis and that other studies have found increased symptom rates, and often significant differences, between bathers and non-bathers in sea waters where the levels of faecal contamination were well below those reported in table $\mathrm{I}^{7}{ }^{10-12} 20$

Both nausea/feeling sick and stomach pains/ cramps increased significantly in both groups and may reflect increases in the consumption of traditional holiday fare. This, compounded with increases in exercise, could give rise to "tummy pains". However, these gastrointestinal symptoms are rather "soft" and highly subjective. ${ }^{21}$ One child might complain of "feeling sick", another of "stomach pains", another not at all. However, it is highly unlikely that this information would account for the differential symptom 
tion would account for the differential symptom reporting observed between the two groups.

Sunburn, on the other hand, was associated with the contact group only and may reflect differences in the amounts of clothing worn by those children who swam, paddled, or played by the water and those who did not. Itchy skin, while not associated with sunburn, might have been due to greater contact with abrasives such as sand or pathogens, either from the sea or animal excrement on the beach. Two of the symptoms which showed significant increases cannot easily be explained, namely blocked nose and headache. Although blocked nose was associated with weekly household income $(p<0.0399)$ for those children in the no contact group, further analyses showed that neither of these symptoms was associated with any of the other symptoms.

We believe that this study has found strong evidence to suggest that those children who come into contact with sea water which fails to meet the designated recreational water standards are significantly more likely to suffer from symptoms such as vomiting, diarrhoea, itchy skin, fever, lack of energy, and loss of appetite, all of which are consistent with contact with sea water contaminated with sewage. What is now open to debate, for children as well as adults, is the severity of that risk. ${ }^{22}$

The authors would like to thank the following people for their assistance with this study: Stephanie Barker (Severn Trent Laboratories) for microbiological assistance; Galen Research and Consultancy (Manchester) for advice on measuring health, questionnaire design, and contributions throughout the study; Pierre Payment (Institut Armand-Frappier, Québec, Canada) for his support in the design of this study, and the day trippers, holidaymakers, and residents of Blackpool who participated in this study. The study was funded by Lancashire County Council.

1 CEC. Council Directive of 8 December 1975 concerning the quality of bathing water (76/160/EEC). Official $\mathcal{f}$ Eur Commun 1976; L 31/1-7.

2 PHLS. Sewage contamination of coastal bathing waters of England and Wales. $₹$ Hyg (Cambs) 1959; 57: 435-72.
3 WHO. Microbiological/epidemiological studies on the correlation between coastal recreational water quality and health effects. Revised Protocol submitted by the WHO Secretariat, ICP/CEH 083/10. Copenhagen: WHO, 1989.

4 Pike EB. Health effects of sea bathing (ET 9511): Phase I-Pilot studies at Langland Bay 1989. WRC Report No DoE 2518-M. Marlow: Water Research Centre, 1990.

5 Brown JM, Campbell EA. The public health implications of sewage pollution of bathing water. Guildford: The Robens Institute, University of Surrey, 1987.

6 Mujeriego R, Bravo JM, Felieu MT. Recreation on coasta waters: public health implications. VIes $\mathcal{F}$ Etude Poll 1982; CIESM: 585-94.

7 Brown JM, Campbell EA, Rickards AD, Wheeler D. Sewage pollution of bathing water. Lancet 1987; ii: 1208-9.

8 Stevenson AH. Studies of bathing water quality and health Am ₹ Public Health 1953; 43: 529-38.

9 Cabelli VJ. Health effects criteria for marine recreational waters. Report No EPA-600/1-80-031. North Carolina: US Environmental Protection Agency, 1983.

10 Cabelli VJ, Dufour AP, McCabe LJ, Levin MA. A marine recreational water quality criterion consistent with indicator concepts and risk analysis. $\mathcal{f}$ Water Poll Contam Fed 1983; 55: 1306-14.

11 Dufour AP. Bacterial indicators of recreational water quality. Can $f$ Public Health 1984; 75: 49-56.

12 Seyfried PL, Tobin RS, Brown NE, Noss PF. A prospective study of swimming-related illness. 1. Swimming-associated health risk. Am F Public Health 1985; 75: 1068-70.

13 Foulon G, Maurin J, Quoi NN, Martin-Bouyer G. Etude de la morbidité en relation avec la pollution bacteriologique des eaux de baignade en mer: etude preliminaire. Rev Franc Sci de L'eau 1983; 2: 127-43.

$14 \mathrm{NJDoH}$. A study of the relationship between illness and ocean beach water quality. Interim Summary Report. New Jersey: beach water quality. Interim Summary Repor

15 Jones F, Kay D, Stanwell-Smith R, Wyer M. Results of the first pilot-scale controlled cohort epidemiological investigation into the possible health effects of bathing in seawater at Langland Bay, Swansea. F IWEM 1991; 5 91-8

16 HMSO. Methods for the isolation and identification of Salmonellae (other than Salmonella typhi) from water and other associated materials. London: HMSO, 1983.

17 Morris R, Waite WM. Evaluation of procedures for recovery of viruses from water. I: Concentration systems. Water Res 1980; 14: 791-3.

18 Morris R, Waite WM. Evaluation of procedures for recovery of viruses from water. II: Detection systems. Water Res 1980; 14: 795-8.

19 Bland M. An introduction to medical statistics. Oxford: Oxford Medical Publications, 1986.

20 Tam TY, Ko KC, Yung H, Broom M. Bacteriological water quality of bathing beaches in Hong Kong, 1989. Environmental Protection Department Report EPD/TR5 89. Hong Kong: Hong Kong Government, 1989.

21 Cabelli VJ, Dufour AP, Levin MA, McCabe LJ, Haberman Cabelli VJ, Dufour AP, Levin MA, McCabe LJ, Haberman PW. Relationship of microbial indicators to health at marine bath

22 Alexander LM, Wheeler D, Heaven A. Recreational water quality and health: Can better management promote bette health for all? Proc Int Conf Environ Pollution 1991; 2 591-9. 